\title{
Synthesis of imidazol-1-yl-acetic acid hydrochloride: A key intermediate for zoledronic acid
}

\author{
Santosh Kumar Singh ${ }^{*}$, Narendra Manne, Purna Chandra Ray \\ and Manojit Pal
}

Open Access

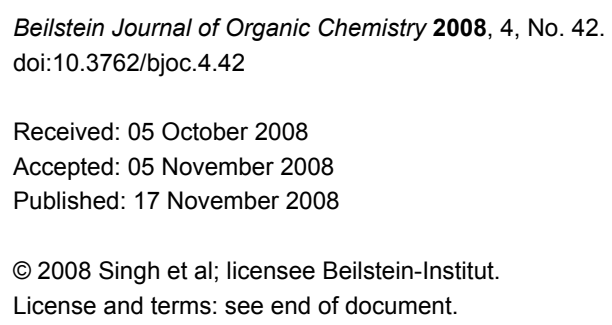

\section{Abstract}

A convenient and practical synthesis of imidazol-1-yl-acetic acid hydrochloride was achieved via N-alkylation of imidazole using tert-butyl chloroacetate followed by a non-aqueous ester cleavage of the resulting imidazol-1-yl-acetic acid tert-butyl ester in the presence of titanium tetrachloride. The synthesized imidazol-1-yl-acetic acid hydrochloride was then utilized to prepare zoledronic acid.

\section{Introduction}

Zoledronic acid (Z, Figure 1) [1-7] is a third-generation bisphosphonate (or diphosphonate) derivative characterized by a side chain that includes an imidazole ring. It inhibits osteoclast action and bone resorption and is used to treat tumorinduced hypercalcemia i.e. a disease condition characterized by the high levels of calcium in the blood (normal range 9-10.5 $\mathrm{mg} / \mathrm{dL}$ or $2.2-2.6 \mathrm{mmol} / \mathrm{L}$ ) usually caused by certain types of cancer. Zoledronic acid is also used along with the cancer chemotherapy to treat bone damage caused by multiple myeloma (a type of cancer of plasma cells that are part of the immune system cells in bone marrow and produce antibodies) or by cancer that began in another part of the body but has spread to the bones. While the use of zoledronic acid can neither suppress nor stop cancer spreading, it can be used to treat bone disease in patients who are suffering from cancer. It works by slowing bone breakdown and decreasing the amount of calcium released from the bones into the blood. It is commer-

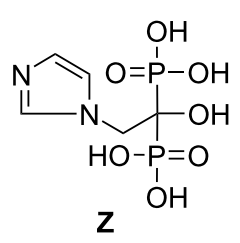

Figure 1: Structure of zoledronic acid. 
cially available in products sold under the brand name Zometa $^{\mathrm{TM}}$ in vials as a sterile powder or solution for intravenous infusion. As part of our ongoing project under the new drug discovery program we had a requirement for compound $\mathbf{Z}$ in quantity. However, we encountered several difficulties while following the existing methods, the most critical one being the isolation of imidazol-1-yl-acetic acid, a key precursor of $\mathbf{Z}$, from aqueous media (see later for a discussion). We then decided to develop a more straightforward and practical route to generate $\mathbf{Z}$, also suitable for its scale-up. Herein we report our detailed study on the synthesis of $\mathbf{Z}$ following a much improved procedure.

\section{Results and Discussion}

Various routes for the preparation of imidazol-1-yl-acetic acid (3), a key precursor of zoledronic acid (Z), have been reported [8-10]. Some of these are summarized in Scheme 1. Thus, imidazol-1-yl-acetic acid tert-butyl ester (2) was synthesized in $50 \%$ yield (Method a, Scheme 1) via the reaction of 2.0 equiv of imidazole (1) with 1.0 equiv of tert-butyl bromoacetate in the presence of an expensive catalyst e.g. bis-[2-( $N$-benzyl- $N, N$ diethylammonio)ethyl]ether dichloride (BBDE $\mathrm{Cl})$ and a combination of bases such as $\mathrm{KOH}-\mathrm{K}_{2} \mathrm{CO}_{3}$ followed by ester hydrolysis in water at $100{ }^{\circ} \mathrm{C}$ [10]. In another process [8] for the preparation of zoledronic acid, a benzyl ester of imidazole-1-ylacetic acid 4 was prepared by reacting imidazole (1) with benzyl chloroacetate generated in situ from benzyl alcohol and chloroacetyl chloride. The ester 4 was then converted to compound 3 either by debenzylation using $10 \% \mathrm{Pd} / \mathrm{C}(50 \%$ wet) or by acidic hydrolysis using $10 \%$ hydrochloric acid (Method b, Scheme 1). The third process [9] involved the reac- tion of methyl chloroacetate with $\mathbf{1}$ in a mixture of solvents followed by hydrolysis to afford the compound $\mathbf{3}$ which was then converted to its hydrochloride salt 6 (Method c, Scheme 1).

It is now evident that all these processes (i) involved a complicated alkylation procedure as a first step, (ii) required the use of an aqueous media in the last step to produce the acid $\mathbf{3}$ and (iii) required an additional step to produce the hydrochloride salt thereby increasing the number of steps. Moreover, due to its high degree of water solubility isolation of compound $\mathbf{3}$ often involved evaporation of water instead of extraction of the aqueous solution by a common organic solvent. All these drawbacks prevented us utilizing any of these known processes for the preparation of $\mathbf{3}$ in large scale.

Our aim was to prepare compound $\mathbf{6}$ avoiding the difficulties mentioned above, particularly the aqueous hydrolysis of the corresponding ester precursor. Our synthesis of $\mathbf{6}$ is shown in Scheme 2. Based on the observations and results of earlier reports (step 1 of Method a, b \& c, Scheme 1) we chose tertbutyl chloroacetate as an efficient and cheaper (compared to tert-butyl bromoacetate) alkylating agent for 1 . Accordingly, compound 2 was prepared by reacting 1 with stoichiometric amount of tert-butyl chloroacetate in the presence of $\mathrm{K}_{2} \mathrm{CO}_{3}$ in refluxing ethyl acetate. After usual work up the desired ester 2 was isolated in $75 \%$ yield. The ester 2 was then treated with $\mathrm{TiCl}_{4}$ in dichloromethane at low temperature to facilitate the non-aqueous cleavage of the tert-butyl ester moiety. Quenching the reaction mixture with $i$-PrOH provided the hydrochloride salt $\mathbf{6}$ as a crystalline solid in the same pot. This step is thus not only free from the use of aqueous media but also avoids

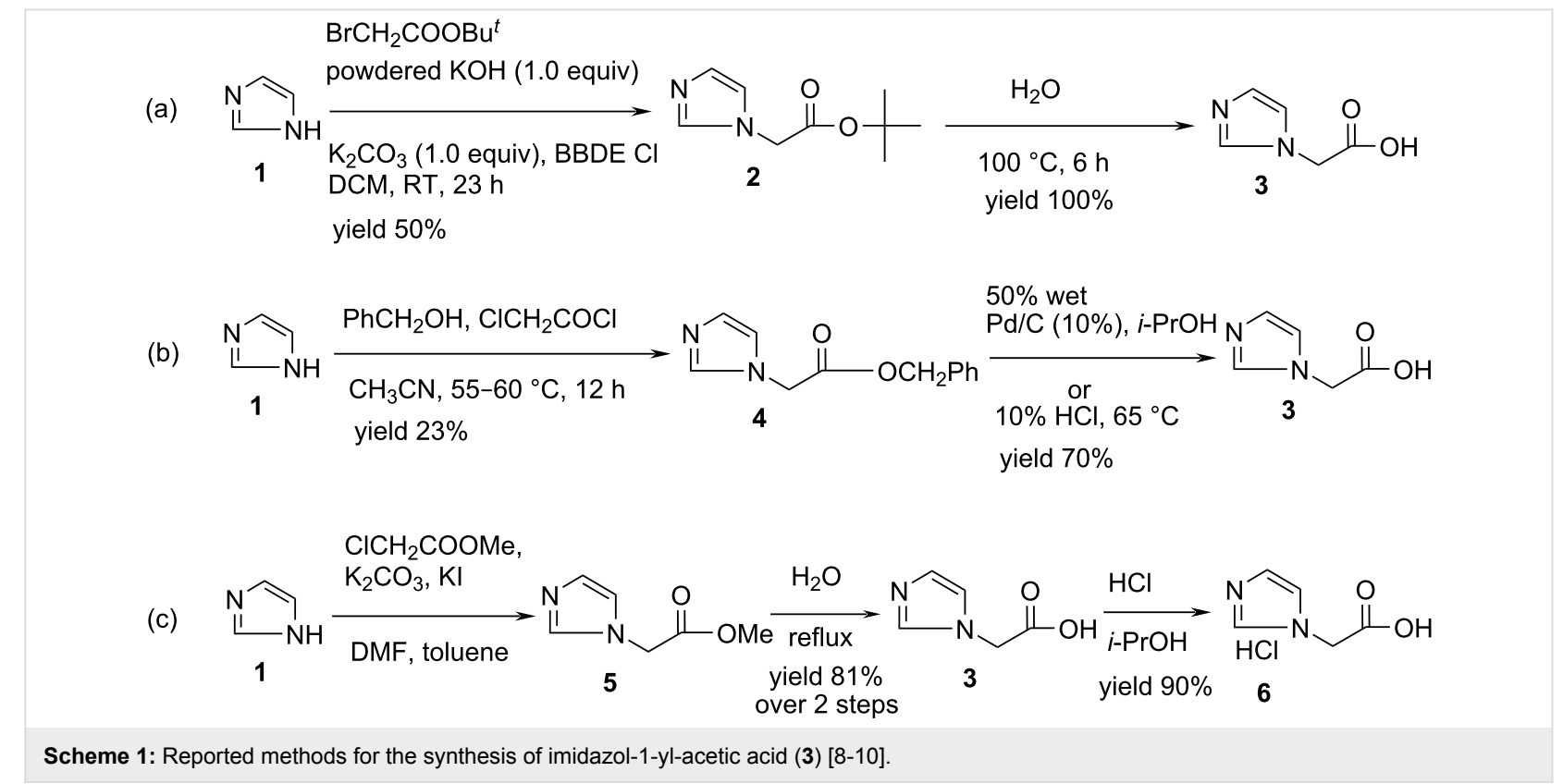


aqueous work up followed by extraction with an organic solvent. Moreover, the hydrochloride salt 6 was isolated in $83 \%$ yield without using $\mathrm{HCl}$. Determination of $\mathrm{HCl}$-content indicated that the compound $\mathbf{6}$ contains $\sim 1.0 \mathrm{~mol}$ of $\mathrm{HCl}$ along with $3.25 \%$ moisture. While the use of $\mathrm{TiCl}_{4}$ for the selective cleavage of tert-butyl ethers is a well known process [11] and has been studied for the cleavage of an ester in a cephalosporin derivative earlier [12], isolation of a hydrochloride salt product directly from the same reaction mixture is not common. A plausible mechanism for $\mathrm{TiCl}_{4}$ mediated cleavage of tert-butyl ester followed by salt formation in tandem is shown in Scheme 3. It is expected that interaction of the ester oxygen with $\mathrm{TiCl}_{4}$ facilitates the cleavage of the $\mathrm{C}-\mathrm{O}$ bond attached to the tertbutyl group. The $\mathrm{HCl}$ generated during this conversion is trapped by the imidazole (to form a salt). Treatment with $i$-PrOH produces the desired acid 6 .

Having prepared the key intermediate $\mathbf{6}$, it was converted to zoledronic acid (7) in 57\% yield by reacting with $\mathrm{H}_{3} \mathrm{PO}_{3}$ and $\mathrm{POCl}_{3}$ according to the procedure shown in Scheme 2.

\section{Conclusion}

In conclusion, we have reported a practical two-step direct synthesis of imidazol-1-yl-acetic acid hydrochloride, a key intermediate for the synthesis of zoledronic acid, in more than $5 \mathrm{~g}$ scale. Unlike earlier routes, the present process is free from the use of aqueous hydrolysis step thereby evaporation of water, and environmentally harmful hydrochloric acid.

\section{Experimental General methods}

All the compounds synthesized were characterized by NMR, IR and MS spectra. ${ }^{1} \mathrm{H}$ NMR \& ${ }^{13} \mathrm{C}$ NMR spectra were recorded on a Bruker Avance 300 spectrometer $(300 \mathrm{MHz})$. Electrospray $\left(\mathrm{ES}^{+}\right)$mass spectra were acquired on an ion trap mass spectrometer.

\section{Preparation of imidazol-1-yl-acetic acid tert- butyl ester (2)}

To a solution of imidazole $(10.0 \mathrm{~g}, 0.15 \mathrm{~mol})$ in ethyl acetate $(160 \mathrm{~mL})$ was added powdered $\mathrm{K}_{2} \mathrm{CO}_{3}(29.0 \mathrm{~g}, 0.21 \mathrm{~mol})$ followed by tert-butyl chloroacetate $(25.7 \mathrm{~mL}, 0.18 \mathrm{~mol})$ at room temperature and the mixture was refluxed for $10.0 \mathrm{~h}$. After completion of the reaction as indicated by TLC $(10 \%$ $\mathrm{MeOH} / \mathrm{CHCl}_{3}, \mathrm{I}_{2}$ active), the reaction mass was quenched with cold water $(80 \mathrm{~mL})$ and the ethyl acetate layer was separated. The aqueous layer was extracted with ethyl acetate $(2 \times 80 \mathrm{~mL})$ and the combined ethyl acetate layers were washed with brine, dried with anhydrous sodium sulfate and then concentrated under vacuum. The resulting solid was stirred with hexane (50 $\mathrm{mL})$ at RT, filtered and washed with hexane $(2 \times 20 \mathrm{~mL})$ to afford the title compound as an off-white solid (20.0 g, 75\%). mp: $111.3-113.2^{\circ} \mathrm{C}$ (Lit [10]: $111-113{ }^{\circ} \mathrm{C}$ ). IR $\left(\mathrm{cm}^{-1}\right)$ : 3458 , 3132, 3115, 2999, 2981, 2884, 1740, 1508, 1380, 1288, 1236, 1154, 1079, 908, 855, 819, 745, 662, 583; ${ }^{1} \mathrm{H}$ NMR (300 MHz, $\left.\mathrm{CDCl}_{3}\right) \delta 1.47(\mathrm{~s}, 9 \mathrm{H}), 4.58(\mathrm{~s}, 2 \mathrm{H}), 6.94(\mathrm{~s}, 1 \mathrm{H}), 7.09(\mathrm{~s}, 1 \mathrm{H})$, $7.49(\mathrm{~s}, 1 \mathrm{H}) ;{ }^{13} \mathrm{C}$ NMR $\left(75 \mathrm{MHz}, \mathrm{CDCl}_{3}\right) \delta 27.7,48.6,82.9$,

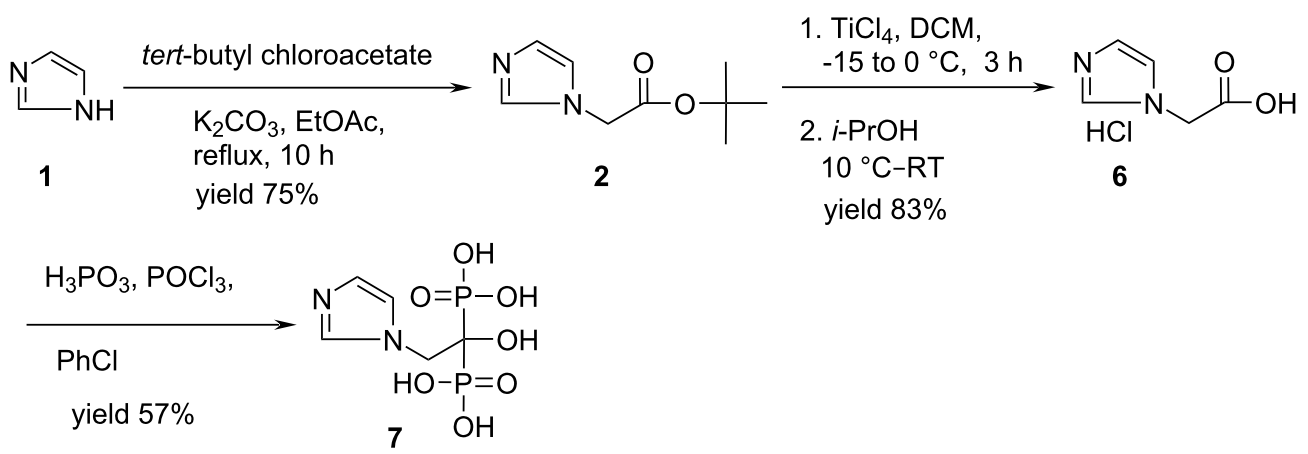

Scheme 2: Preparation of imidazol-1-yl-acetic acid hydrochloride (6) and its conversion into zoledronic acid (7).

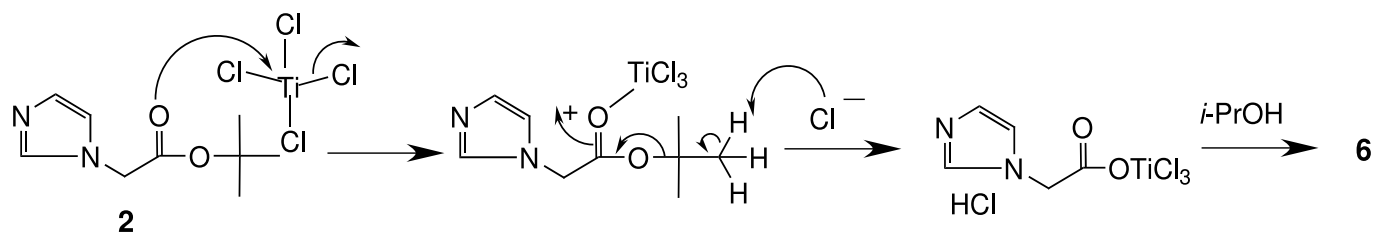


119.8, 129.2, 137.7, 166.3; MS $(m / z) 183.0[\mathrm{M}+1,100 \%]$, 127.0.

\section{Preparation of imidazol-1-yl-acetic acid hydrochloride (6)}

To a solution of imidazol-1-yl-acetic acid tert-butyl ester (2) $(10.0 \mathrm{~g}, 0.05 \mathrm{~mol})$ in dichloromethane $(100 \mathrm{~mL})$ was added titanium tetrachloride $(8.0 \mathrm{~mL}, 0.07 \mathrm{~mol})$ dropwise slowly at -15 to $-10{ }^{\circ} \mathrm{C}$ over $1 \mathrm{~h}$ and the mixture was stirred at -5 to $0{ }^{\circ} \mathrm{C}$ for $2 \mathrm{~h}$. Isopropyl alcohol $(25 \mathrm{~mL})$ was added at 0 to $-10^{\circ} \mathrm{C}$ over $0.5 \mathrm{~h}$ and the reaction mass was stirred at room temperature for $0.5 \mathrm{~h}$. Additional isopropyl alcohol $(125 \mathrm{~mL})$ was added dropwise at room temperature over $0.5 \mathrm{~h}$ and the mixture was stirred for $1 \mathrm{~h}$. Dichloromethane was distilled out under a low vacuum and the resulting crystalline solid precipitated was filtered to afford the title compound as an off-white crystalline solid (7.4 g, 83\%). mp 200.3-202.3 ${ }^{\circ} \mathrm{C}$; IR $\left(\mathrm{cm}^{-1}\right): 3175,3125$, 3064, 2945, 2869, 2524, 2510, 1732, 1581, 1547, 1403, 1223 , 1193, 1081, 780, 650; ${ }^{1} \mathrm{H}$ NMR (300 MHz, $\mathrm{D}_{2} \mathrm{O}+3$-(trimethylsilyl)propionic acid sodium salt) $\delta 5.1\left(\mathrm{~s}, 3 \mathrm{H},-\mathrm{CH}_{2^{-}}+\mathrm{HCl}\right), 7.5$ (br s, 2H), 8.7 (s, 1H); ${ }^{13} \mathrm{C}$ NMR (75 MHz, $\mathrm{D}_{2} \mathrm{O}+3$-(trimethylsilyl)propionic acid sodium salt) 52.7, 122.4, 125.9, 138.8, 172.8; MS $(\mathrm{m} / \mathrm{z}) 127.0[\mathrm{M}+1,100 \%]$; HCl-content: found $21.8 \%$ (along with $3.25 \%$ moisture), calcd $22.43 \%$ for $\mathrm{C}_{5} \mathrm{H}_{6} \mathrm{~N}_{2} \mathrm{O}_{2} \cdot \mathrm{HCl}$.

\section{Preparation of zoledronic acid (7)}

To a suspension of imidazol-1-yl-acetic acid hydrochloride (6) $(7.0 \mathrm{~g}, 0.043 \mathrm{~mol})$ and phosphorous acid $(9.5 \mathrm{~g}, 0.116 \mathrm{~mol})$ in chlorobenzene $(50 \mathrm{~mL})$ was added phosphorous oxychloride $(9.6 \mathrm{ml}, 0.103 \mathrm{~mol})$ at $80-85^{\circ} \mathrm{C}$ over a period of $2 \mathrm{~h}$ then heated to $90-95{ }^{\circ} \mathrm{C}$ for $2.5 \mathrm{~h}$. The reaction mass was cooled to $60-65{ }^{\circ} \mathrm{C}$ and water $(100 \mathrm{~mL})$ was added at the same temperature. The aqueous layer was separated, collected and refluxed for $18 \mathrm{~h}$. It was then cooled to room temperature and diluted with methanol $(140 \mathrm{~mL})$. The mixture was cooled to $0-5{ }^{\circ} \mathrm{C}$ and stirred for $3 \mathrm{~h}$. The precipitated solid was filtered, washed with cold water followed by methanol and then dried under vacuum at $60{ }^{\circ} \mathrm{C}$ for $12 \mathrm{~h}$ to afford the title compound $(6.6 \mathrm{~g}, 57 \%$ yield $)$ as a white solid; mp $237-239^{\circ} \mathrm{C}$ (lit [1] $239^{\circ} \mathrm{C}$ with decomposition).

\section{Supporting Information}

\section{Supporting Information File 1}

${ }^{1} \mathrm{H}$ and ${ }^{13} \mathrm{C}$ NMR spectra of compound 2 and $\mathbf{6}$.

[http://www.beilstein-journals.org/bjoc/content/

supplementary/1860-5397-4-42-S1.doc]

\section{Acknowledgments}

The authors thank management of Matrix Laboratories Limited for constant encouragement and support. The authors also thank the Analytical Department for spectral and analytical data.

\section{References}

1. Sorbera, L. A.; Rabasseda, X.; Castañer, J. Drugs Future 2000, 25, 259-268. doi:10.1358/dof.2000.025.03.569207

2. Lifshitz-Liron, R.; Lidor-Hadas, R. Process for Purification of Zoledronic Acid. PCT Int. Pat. Appl. WO 2004/075860, September 10, 2004.

3. Widler, L.; Jaeggi, K. A.; Glatt, M.; Müller, K.; Bachmann, R.; Bisping, M.; Born, A.-R.; Cortesi, R.; Guiglia, G.; Jeker, H.; Klein, R.; Ramseier, U.; Schmid, J.; Schreiber, G.; Seltenmeyer, Y.; Green, J. R. J. Med. Chem. 2002, 45, 3721-3738. doi:10.1021/jm020819i

4. Kieczykowski, G. R.; Jobson, R. B.; Melillo, D. G.; Reinhold, D. F.; Grenda, V. J.; Shinkai, I. J. Org. Chem. 1995, 60, 8310-8312. doi:10.1021/jo00130a036

5. Jaeggi, K. A.; Widler, L. Substituted Alkanediphosphonic Acids and Pharmaceutical Use. U.S. Patent 4,939,130, July 3, 1990.

6. De Ferra, L.; Turchetta, S.; Massardo, P.; Casellato, P. Preparation of Biphosphonic Acids and Salts Thereof. U.S. Pat. Appl. 2005/0288509, December 29, 2005.

7. Patel, V. M.; Chitturi, T. R.; Thennati, R. A Process for Preparation of Bisphosphonic Acid Compounds. PCT Int. Pat. Appl. WO 2005/044831, May 19, 2005.

8. Patel, V. M.; Chitturi, T. R.; Thennati, R. A Process for the Preparation of 2-(Imidazol-1-yl)-1-hydroxyethane-1,1-diphosphonic Acid. PCT Int. Pat. Appl. WO 2005/066188, July 21, 2005.

9. Pulla Reddy, M.; Usha Rani, V.; Venkaiah Chowdary, N. An Improved Process for the Preparation of Zoledronic Acid. PCT Int. Pat. Appl. WO 2005/063717, July 14, 2005

10. Zaderenko, P.; Gil, M. S.; Ballesteros, P.; Cerdán, S. J. Org. Chem. 1994, 59, 6268-6273. doi:10.1021/jo00100a030

11. Schlessinger, R. H.; Nugent, R. A. J. Am. Chem. Soc. 1982, 104, 1116-1118. doi:10.1021/ja00368a044

12. Valencic, M.; van der Does, T.; de Vroom, E. Tetrahedron Lett. 1998, 39, 1625-1628. doi:10.1016/S0040-4039(97)10857-7

\section{License and Terms}

This is an Open Access article under the terms of the Creative Commons Attribution License (http://creativecommons.org/licenses/by/2.0), which permits unrestricted use, distribution, and reproduction in any medium, provided the original work is properly cited.

The license is subject to the Beilstein Journal of Organic Chemistry terms and conditions: (http://www.beilstein-journals.org/bjoc)

The definitive version of this article is the electronic one which can be found at: doi:10.3762/bjoc. 4.42 